\title{
Population Size, Activity Patterns, Diet, and Ranging Ecology of Boutourlini's Blue Monkey (Cercopithecus mitis boutourlinii) in Apini and Dokuma Forests, Awi Zone, Ethiopia
}

Zemenu Birhan ( $\sim$ zedbirhan12@gmail.com )

Bonga University

Dessalegn Ejigu

Bahir Dar University

Research Article

Keywords: Block count method, Boutourlini's blue monkey, scans sampling, subspecies, wet and dry seasons

Posted Date: May 21st, 2021

DOI: https://doi.org/10.21203/rs.3.rs-443919/v1

License: (a) This work is licensed under a Creative Commons Attribution 4.0 International License. Read Full License 


\section{Abstract}

Background: By studying population size, activity patterns, diet, and ranging ecology of Boutourolini's blue monkey (Cercopithecus mitis boutourlinii) we can get sufficient information to conserve the subspecies in the area. Boutourlini's blue monkey is endemic subspecies found in the western and northwestern parts of Ethiopia. The study was conducted in Apini and Dokuma forests, northwestern Ethiopia, from October 2018 to June 2019. The block count method was used to estimate its total population size and scan sampling method was used to collect data for activity patterns, and diet. The ranging ecology of the study subspecies was determined for each group based on the point to point movements of the group between consecutive GPS locations recorded.

Results: On average a total of 71 and 111 individuals of Boutourolini's blue monkey were counted in Apini and Dokuma forests, respectively. Boutourolini's blue monkey spent $47.5 \%$ and $48.6 \%$ of time feeding, $20.2 \%$ and $18.6 \%$ moving, and $14.1 \%$ and $13.5 \%$ resting by the Apini and Dokuma groups, respectively. The Apini group frequently fed on young leaves (52.8\%), fruits (30.2\%), and mature leaves (6.6\%), while the Dokuma group fed on young leaves (39.8\%), fruit 942.3\%), and mature leaves (8.3\%). Ranging ecology of Boutourolini's blue monkey was 44.4 ha and 78.3 ha for the Apini group, and 51 ha and 56.9 ha for the Dokuma group during the wet and dry seasons, respectively.

Conclusions: The total population size of blue monkeys in the Apini and Dikuma forests counted were different. Activity budgets vary during the wet and dry seasons. During the entire study period blue monkeys consumed different food items from the two forests. The home range size of blue monkeys during the two seasons was different in both groups and they traveled long distance during the dry season. As the habitats of Boutourolini's blue monkey in the present study area is degraded due to various anthropogenic activities, there is a need to design strategies to minimize conservation problems of the subspecies in the area.

\section{Background}

Most primate species including blue monkey (Cercopithecus mitis) face ongoing habitat disturbance, yet not all species respond to such disturbance the same way [1, 2]. While many primate species experience declines in population density when their habitats are disturbed, there are several primate species that do not, and these flexible species will generally require less conservation attention [3]. Habitat loss is perhaps the serious threat facing blue monkey inhabiting tropical forests [4]. As a result, they are adversely affected by the fragmentation of their habitat $[5,6]$.

Boutourlini's blue monkey (Cercopithecus mitis boutourlinii) is a subspecies of blue monkeys [7]. According to IUCN (2005), 17 subspecies of blue monkeys are recorded in different parts of Africa, and Boutourlini's blue monkey is one of the endemic subspecies to Ethiopia. It is occurring from Lake Tana southwards along the western side of the Ethiopian Rift Valley [8]. Boutourlini's blue monkey is categorized as vulnerable in the IUCN Red List of threatened species [5].

Blue monkey must optimize their time, and can flexibly adjust their activity budgets to deal with changeable environmental conditions [9]. Fruits are the most frequently used plant components of blue monkey's diet though high amounts of leaves and invertebrates are consumed periodically [10]. Thus, as an omnivore, it 
mostly feeds on fruits, leaves, invertebrates, flowers, seeds, bark and shoots [11]. Understanding an altered diet in fragmented habitats is important for conservation efforts because the shifts can impact many aspects of its ecology and behavior, and ultimately affect survival of the species. Generally, the quality of food resources directly impacts health and body condition, which can affect birth and mortality rates as well as susceptibility to predation and disease [12].

To conserve the endemic Boutourlini's blue monkey in its current habitat, information on its population size, activity pattern, diet, and ranging ecology is very important. Currently, this subspecies is widely distributed in protected areas and remnant forest patches of the western and northwestern parts of Ethiopia including in Apini and Dokuma forests. However, it is not yet studied. The present study, therefore, aimed to estimate population size of the Boutourlini's blue monkey, to describe its activity patterns, to examine its diet, and to determine ranging ecology of the study subspecies in Apini and Dokuma forests.

\section{Results}

\section{Population size}

The average numbers of Boutourlini's blue monkeys counted in the Apini and Dokuma forests were 71 and 111, respectively. The mean number of individuals counted in block 1, block 2, and block 3 in Apini forest were 19.5 \pm SD 2.12, $22 \pm$ SD 4.24, and $29.5 \pm$ SD 2.12, respectively. The mean number of Boutourolini's blue monkey among the three blocks did not show significant difference $\left({ }^{2}=2.73, \mathrm{df}=2, \mathrm{P}>0.05\right)$.

The total number of individuals counted in the Apini forest during the wet and dry seasons were $(n=74)$, and $(n=68)$, respectively. This showed there is no significant difference in population size estimate between the wet and dry seasons $\left({ }^{2}=0.25, d f=1, P>0.05\right)$. The individual numbers of Boutourolini's blue monkey counted in the three blocks in Apini forest is showed below (Fig. 1).

The total numbers of individuals in Dokuma forest during the wet and dry seasons were $(n=118)$, and $(n=104)$, respectively. The highest number of individuals was counted in block 2, while the lowest was counted in block 1. The total number of individuals counted during the wet and dry seasons among the four blocks did not show significant difference $\left({ }^{2}=0.88, \mathrm{df}=1, \mathrm{P}>0.05\right)$. The mean number of individuals counted in block 1 , block 2 , block

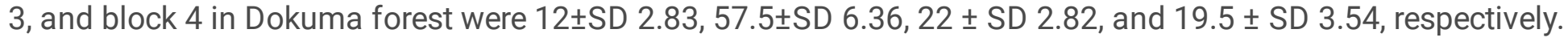
The variations in the mean number of individuals counted between blocks 1 and 2 were statistically significant $\left({ }^{2}=30.22, d f=1, P<0.05\right)$, and the same was true in blocks 2 and $4\left({ }^{2}=18.51, d f=1, P<0.05\right)$. However, there was no significant difference in the mean number of individuals counted between blocks 3 and $4\left({ }^{2}=0.09, d f=1\right.$, $P>0.05)$, and blocks 1 and $3\left({ }^{2}=2.94, d f=1, P>0.05\right)$. The individual numbers of Boutourolini's blue monkey counted in blocks during the wet and dry seasons among the four blocks are shown below (Fig. 2).

In general, the populations size of Boutourlini's blue monkeys in the Apini and Dokuma forests showed a relatively more mean number of individuals in Dokuma forest than in Apini forest, and the difference was significant $\left({ }^{2}=8.79, \mathrm{df}=1, \mathrm{P}<0.05\right)$.

\section{Activity budget}


A total of $n=2436$ individual observations were recorded from 773 scans for the Apini group, and $n=2512$ individual observations were recorded from 822 scans for the Dokuma group. The Apini group spent $47.5 \%$ time feeding, $14.1 \%$ resting, $20.2 \%$ moving, $12.3 \%$ different social activities, and $6.0 \%$ other activities including vocalization, defecation, urination, and looking to the observer. Whereas, the Dokuma group spent $48.6 \%$ of their time feeding, 13.5\% resting, 18.6\% moving, 14.3\% different social activities, and 5.0\% other activities (Fig. 3).

There was no significant difference in time spent on diurnal activity budgets between the Apini and Dokuma groups $\left({ }^{2}=1.17, d f=1, P>0.05\right)$.

Boutourlini's blue monkey of the Apini group on average spent $48.1 \%$ of the time feeding and $17.9 \%$ of the time resting during the wet season, and $46.8 \%$ feeding and $9.8 \%$ resting during the dry season. However, they spent relatively more time $25.6 \%$ moving and $7.0 \%$ for other activities during the dry season than the wet season which were $15.4 \%$ moving, and $5.0 \%$ other activities. There were statistically significant differences in time spent feeding $\left({ }^{2}=5.12, d f=1, P<0.05\right)$, resting $\left({ }^{2}=39.91, d f=1, P<0.05\right)$, moving $\left({ }^{2}=20.24, d f=1, P<0.05\right)$, and grooming $(2=7.47, \mathrm{df}=1, \mathrm{P}<0.05)$ in the Apini group between the wet and dry seasons.

The Dokuma group on average spent relatively more time feeding (51.5\%) during the wet season than during the dry season (45.4\%). They also spent relatively more time moving (21.9\%) during the dry season than the wet season (15.6\%) (Table 1).

There were significant difference in time spent feeding $\left({ }^{2}=19.40, d f=1, P<0.05\right)$, resting $\left({ }^{2}=7.39, d f=1, P<0.05\right)$, and moving $\left({ }^{2}=5.14, d f=1, P<0.05\right)$ for the Dokuma group between the wet and dry seasons.

\section{Dietary ecology}

A total of $n=1157$ feeding observations were recorded from 381 scan samplings in the Apini group, and $n=1222$ feeding observations were recorded from 400 scan samplings in the Dokuma group. For the Apini group, young leaves contributed $52.8 \%$ of food items of blue monkey which was the highest proportion of food items foraged. Fruits and mature leaves made the second and third largest contributions of its diet with $30.2 \%$ and $6.6 \%$, respectively. Flowers (3.3\%) and tree buds (2.5\%) made the least contributions of the diet (Fig. 4).

The most frequently consumed food item in Dokuma group was the fruit which contributed $42.3 \%$ of the diet. Young leaves were the second most frequently consumed food items which accounted for $39.8 \%$ of the diet. Mature leaves and tree buds were the third and the fourth most consumed food items which made $8.3 \%$ and $4.6 \%$, respectively, of its diet. Other food items consumed were stems, flowers, seed and animal preys which accounted for $0.5 \%, 1.2 \%, 1.8 \%$ and $1.6 \%$, respectively, of the diet. There was significant difference in time spent feeding young leaves $\left({ }^{2}=14.24, d f=1, P<0.05\right)$, fruit $\left({ }^{2}=32.59, d f=1, P<0.05\right)$, tree buds $\left({ }^{2}=8.57, d f=1, P<0.05\right)$, stem $\left({ }^{2}=11.64, d f=1, P<0.05\right)$, and flowers $\left({ }^{2}=9.98, d f=1, P<0.05\right)$ between the Apini and Dokuma groups.

Boutourlini's blue monkeys in the Apini forest spent $62.7 \%$ of time feeding on young leaves, and $7.5 \%$ of mature leaves during the wet season than the dry season which accounts $41.5 \%$, and $5.6 \%$, respectively. However, they spent $39.3 \%$ of time feeding on fruits, and $5.1 \%$ on flowers during the dry season than the wet season $22.2 \%$, and $1.1 \%$, respectively. There was significant difference in time spent feeding on young leaves $\left({ }^{2}=43.48, d f=1\right.$, 
$P<0.05)$, fruits $\left({ }^{2}=16.11, d f=1, P<0.05\right)$, tree buds $\left({ }^{2}=7.75, d f=1, P<0.05\right)$, and flowers $\left({ }^{2}=15.15, d f=1, P<0.05\right)$ between the wet and dry seasons in the Apini group.

In the Dokuma forest, they spent $44.9 \%$ of time feeding on young leaves, $9.2 \%$ on mature leaves, and $4.9 \%$ on tree buds during the wet season than the dry season which were $33.1 \%, 7.1 \%$, and $4.1 \%$, respectively. However, they spent $49.1 \%$ of time feeding on fruits, and $2.4 \%$ on flowers during the dry season than the wet season which was $37.1 \%$, and $0.3 \%$, respectively (Table 2 ).

There was a significant difference in time spent feeding young leaves $\left({ }^{2}=35.85, d f=1, P<0.05\right)$, mature leaves $\left({ }^{2}=6.18, d f=1, P<0.05\right)$ and flowers $\left({ }^{2}=8.06, d f=1, P<0.05\right)$ between the wet and dry seasons in the Dokuma group.

Boutourolini's blue monkey of the Apini and Dokuma groups consumed a total of 14 plant species in their overall diet during the study period (Tables 3 and 4). In the Apini forest, the highest contribution of the diet was from the Albizia gummifera (33.7\%), and Hyppocratea spp. (29.1\%), while in the Dokuma forest, the most consumed plant species in the percentage contribution was Hyppocreatea spp. which accounted (35.1\%), and Albizia gummifera (24.7\%).

\section{Ranging ecology}

Ranging ecology of Boutourlini's blue monkeys in the Apini group during the wet and the dry seasons were 44.4 ha and 78.3 ha, respectively (Fig. 5) whereas the ranging ecology of Boutourlini's blue monkeys in the Dokuma group during the wet and the dry seasons were 51 ha and 56.9 ha, respectively (Fig. 6).

There was a significant difference between the wet and dry seasons in the home range size of blue monkeys in the Apini group $\left({ }^{2}=9.47, d f=1, P<0.05\right)$. However, there was no significant difference between seasons in the home range size of the Dokuma group $\left({ }^{2}=0.33, \mathrm{df}=1, \mathrm{P}>0.05\right)$.

The mean daily range distance for the Apini group during the wet and the dry seasons were $648 \mathrm{~m}$, and $732 \mathrm{~m}$, respectively whereas for the Dokuma group the mean day range distance during the wet and the dry seasons were $715 \mathrm{~m}$ and $774 \mathrm{~m}$, respectively. There was significant difference in the daily range lengths of blue monkeys of the Apini group between the wet and dry seasons $(2=5.11, d f=1, P<0.05)$. However, in the Dokuma group, the difference did not show significant difference between the two seasons $\left({ }^{2}=2.33, d f=1, P>0.05\right)$.

\section{Discussion}

Boutourlini's blue monkey is one of the endemic primate subspecies of Ethiopia. Blue monkeys are strictly associated with primary tropical deciduous and riverine forest [8]. However, the present study area is classified as moist Afro-montane forests with different vegetation strata within tree dominated habitats [13].

The population size of Boutourlini's blue monkeys in the Dokuma forest is more than the Apini forest. This might be because the total area of Dokuma forest is relatively larger than the Apini forest. The total number of individuals counted in Apini and Dokuma forests during the wet season is more than the dry season. This might be because during the wet season there is sufficient food availability that makes the Boutourlini's blue monkey concentrated at specific habitats as a result we can get sufficient data for population census. During the dry 
season most trees drop their leaves and become deciduous and individuals are sparsely distributed throughout the entire forest that makes population count not easier as during the wet season. Similarly, [14] estimated more numbers of Boutourlini's blue monkey during the wet season than the dry season. The densities of primates are directly related to the availability and distribution of food tress [15].

The result of this study showed that the seasonal and the overall activity time budgets of Boutourlini's blue monkey showed that feeding as the predominant activity, accounting for $47.5 \%$ of the time spent in the Apini, and $48.6 \%$ in the Dokuma than other diurnal activities such as moving, resting, and socialization. Similarly, [16] and [17] found that monkeys spent more time feeding than other diurnal activities followed by moving and resting. Boutourlini's blue monkey activity time budgets showed variation with other Cercopithecines or guenons. They spent more time feeding and socializing compared to Cercopithecus Ihoesti and Cercopithecus mitis doggeti and they spent less time moving and resting than other Cercopithecines (Table 5). In addition, when compared to $C$. mitis stuhlmanni and $C$. campbeelli, blue monkeys spent less time in feeding, resting and moving activities. However, they spent more time socializing and other activities.

Boutourlini's blue monkey classified as folivores and frugivores. They foraged different food items and mostly, they feed $52.8 \%$ of the time on young leaves, and $30.2 \%$ on fruits in the Apini, and $39.8 \%$ of the time on young leaves, and $42.3 \%$ on fruits in the Dokuma forest. Fruits accounted $45.8-57.1 \%$ of their food source for blue monkey [18]. This showed that they considered as folivores and frugivores. Similarly, [19] showed that Boutourlini's blue monkey spent more time feeding on young leaves and fruits.

In the present study, the Apini and Dokuma groups spent most of the time constantly feeding on young leaves on different trees and fruits of lianas during the study period. This might be due to the high abundance of leaves and fruiting lianas in both sites. Similarly, groups of Boutourlini's blue monkeys spent most of their time feeding on leaves of different herbs, lianas and trees as studied by [17]. In addition, Boutourlini's blue monkey spent most of their time feeding on young leaves and fruits of different plants in Komto protected forest, Ethiopia [20].

Boutourlini's blue monkeys of the group devoted more time foraging on young leaves and fruits in the Apini and Dokuma forests during the wet and dry seasons. [21] indicated that young leaves have more protein, low fiber content and are easily digestible than mature leaves. They showed seasonal variation by consuming young leaves during the wet season as young leaves are more abundant in the area. The feeding time budget for the Apini group was almost the same in both seasons whereas the feeding time budget for the Dokuma group showed some variation between the two seasons. In the same way, the feeding activity of one group showed no variation between the two seasons, while the other groups showed some variation between the two seasons [19].

In Dokuma forest, fruits are the most sources of food items of Boutourlini's blue monkey that they spent more time on fruits than young leaves. This might be due to the relatively high abundance of fruits of Hyppocratea $s p p$. available throughout the study period in the Dokuma forest. This might be when there are no enough leaves available in the area; they invest their time feeding on fruits during the dry season than the wet season. The dry season is the time for most fruiting plants to bear fruits. Boutourlini's blue monkey showed high movement patterns to encounter fruits when there is scarcity of food [22]. Similarly, Colobus guereza spent more time feeding on fruits due to the high abundance of fruits during the dry season than the wet season [23]. 
Similarly, they spent more time feeding on fruits than young leaves during the dry season in the Jibat forest, Ethiopia [19]. In addition, [16] suggested that Bale monkeys (Chlorocebus djamdjamensis) spent more time feeding on fruits during the dry season. Similarly, C. guereza spent more time feeding on fruits during the dry season than the wet season [24]. Boutourlini's blue monkey at Apini and Dokuma forests feed more on young leaves and matured leaves compared to other Cercopithecus spp. (Table 6).

The ranging ecology is the area in which an animal normally travels in pursuit of its routine activities. In primates, primarily frugivores species generally have larger home ranges for their bodily sizes than those of folivores or herbivores species [25]. However, Boutourlini's blue monkeys are both folivores and frugivores species. In the present study the home range size of Boutourlini's blue monkeys during the dry season was greater than the wet season as they traveled more distance during the dry season in search of food and water. This is because during the dry season there is scarcity of food, and hence to search for food both groups traveled long distance. Similarly, the study conducted by [16] on Bale monkeys showed that they traveled long

distance during the dry season than the wet season which is linked to the need to search fruits. In addition, [19] described that blue monkeys traveled longer distances during the dry season than the wet season.

\section{Conclusion}

Study about population size and diurnal activity patterns of blue monkeys could give important information about this species. The population size of blue monkeys in the Apini and Dikuma forests were counted by using study blocks. Boutourlini's blue monkeys spent most of their activity time budgets on feeding and moving. Activity budgets vary during the wet and dry seasons. During the entire study period blue monkeys consumed different food items from the two forests. Thus, young leaves, fruits, mature leaves, shoots, flowers and seeds were consumed from variety of plant species during the wet and dry seasons. Blue monkeys consumed different plant species in the study sites.

The home range size of blue monkeys during the two seasons was different in both groups and they traveled long distance during the dry season. Since Boutourlini's blue monkeys never engaged in crop raiding there was no conflict with the local people. However, this subspecies is threatened due to habitat destruction since there is high deforestation of the habitats and agricultural expansion by local people. Moreover they are threatened by the predator leopard as witnessed by the local people. In addition, local people in the nearby forest extracted woods from the forest for different purposes such as fuel wood, house construction, furniture and for other purposes. Hence, the forest habitat is constantly changing in size and quality which may not support different wildlife species including blue monkeys.

Management action should be practiced or implemented to conserve the forest and awareness creation among local people about the importance of forests and how they protect and manage it from different anthropogenic activities should be forwarded. In addition, further investigation should be conducted to determine the sustainable and beneficial level of harvesting some plant species mainly Albizia gummifera and other important plants to participate the local people in benefit sharing so that they become responsible to ensure sustainable conservation of resources in the area.

\section{Methods}




\section{Description of the study area}

The present study was conducted in two forest patches of Awi Administrative Zone, namely Apini and Dokuma forest patches, which are located $33 \mathrm{~km}$ west of Injibara town, the capital of Awi Administrative Zone, and 480 $\mathrm{km}$ northwest of Addis Ababa. Apini forest patch lies between $11^{\circ} 1{ }^{\prime} 39.22^{\prime \prime} \mathrm{N}$ to $11^{\circ} 2^{\prime} 30.18^{\prime \prime} \mathrm{N}$ latitudes, and $36^{\circ} 41^{\prime} 0.90^{\prime \prime} \mathrm{E}$ to $36^{\circ} 41^{\prime} 36.00^{\prime \prime} \mathrm{E}$ longitudes, with the altitudes range of $2031 \mathrm{~m}$ to $2186 \mathrm{~m}$ a. s. I., and Dokuma forest patch lies between $10^{\circ} 58^{\prime} 33.22^{\prime \prime} \mathrm{N}$ to $10^{\circ} 59^{\prime} 30.17^{\prime \prime} \mathrm{N}$ latitudes, and $36^{\circ} 39^{\prime} 55.58^{\prime \prime} \mathrm{E}$ to $36^{\circ} 40^{\prime} 28.00^{\prime \prime} \mathrm{E}$ longitudes, with the altitudes range of $2040 \mathrm{~m}$ to of $2105 \mathrm{~m}$ a. s. I. (Fig. 7).

The total size of Apini and Dokuma forests are 139 ha and 226 ha, respectively. The distance between Apini and Dokuma forests is $3 \mathrm{~km}$, and the two forests are almost similar in vegetation composition and structure. The different vegetation structures include trees, shrubs, and grasses. The dominant tree species in both study sites are Ficus vasta, Croton macrostachyus, Rosa abyssinica, Acacia abyssinica, Buddleja polystachya, Cordia africana, Olea sepecies, Albizia species, Apodytes dimidiate, Ekebergia capensis, Prunus africana, Schefflera abyssinica, Rhus glutinosa, Pittosporum viridiflorum [13]. Both are community protected forests even if the habitats are degraded as a result of deforestation by the local people. These forests are used as home to different wildlife species including Cercopithecus mitis boutourlinii, Colobus guereza, Papio anubis, Chlorocebus aethiops, Crocuta crocuta, Panthera pardus, and Sylvicapra grimmia.

The climate data was obtained from Bahir Dar town, West Amhara Meteorology Agency which is $153 \mathrm{~km}$ from the study area showed a uni-modal rainfall distribution with heavy rainfall from June to September. The highest intensity of rainfall occurs in August with $464.1 \mathrm{~mm}$. The mean annual rainfall from a period of 2009 to 2018 was $1690.2 \mathrm{~mm}$, and the mean monthly minimum and maximum temperature records were $10.8^{\circ} \mathrm{C}$ in December, and $31^{\circ} \mathrm{C}$ in April, respectively (Fig. 8).

\section{Study species and groups}

Boutourlini's blue monkey is medium-sized, short-tailed arboreal primate which is endemic to Ethiopia. The behavioral study was conducted on two groups from both forests after a period of two months of habituation with the two study groups.

\section{Abbreviations}

GPS: Global Positioning System; IUCN: International Union for the Conservation of Nature; KDE: Kernel Density Estimations; SPSS: Statistical Package for the Social Sciences; SD: Standard Deviation

\section{Declarations}

\section{Ethics approval and consent to participate}

The study was approved by institutional review board (IRB) guideline and regulation of college of Sciences at Bahir Dar University, Ethiopia. Permission for the study to be conducted was also obtained from office of Kidamaja kebele and from Awi Administrative Zone office.

\section{Funding}


Not funding available

\section{Authors' contribution}

ZB and DE proposed the research idea and collected the behavioral data of Boutourlini's blue monkey. ZB organized the data in computer and did the analysis, interpretation and wrote the manuscript. DE revised the manuscript for scientific content and did check the language. The authors read and approved the final manuscript.

\section{Availability of data and materials}

The data used and analyzed during the current study is available in the hand of corresponding author for further request if request is available from reviewers without disclosure of the interviewees.

\section{Consent for publication}

This manuscript does not contain any individual person's data, and further consent for publication is not required.

\section{Competing interests}

On the behalf of all authors there is no competing interest.

Acknowledgments: We are very grateful to Bahir Dar University, College of Science, Department of Biology for allowing us to use field equipment during data collection period. We thank West Amhara Meteorology Agency Office for giving the temperature and rainfall data of the study area. The contribution of Dr. Amera Moges in sharing ideas, giving practices for behavioral scan sampling data collection method and giving additional field equipment is highly indebted. We also very grateful to Dr. Ali Seid for his professional help in the identification of plant species collected from the study sites. We owe great thanks to Mengistu Birhan for his valuable support rendered during the data collection period. Last but not least, we thank the community members and local guides of the study areas who give us support during the whole study period. We owe great thanks to anonymous reviewers for their great contribution in providing comments to improve the manuscript.

\section{References}

1. Chapman CA \& Peres CA. Primate conservation in the new Millennium: the role of scientists. Issues, News, and Reviews, Evolu Anthrop. 2001; 10:16-33.

2. Fashing PJ. Population status of black and white colobus monkeys (Colobus guereza) in Kakamega Forest, Kenya: are they really on the decline? Afr Zool. 2002; 37: 119-126.

3. Cowlishaw G, Dunbar RI. Primate Conservation Biology. University of Chicago Press, Chicago; 2000.

4. The IUCN Red List of Threatened Species, 2012 Available at: http:// www.iucnredlist.org.

5. De Jong YA, Butynski TM Cercopithecus mitis ssp. boutourlini. The IUCN Red List of threatened species. 2020; https://dx.doi.org/10.2305/IUCN.UK.

6. Mekonnen A, Fashing PJ, Afework Bekele \& Stenseth N Ch. Distribution and conservation status of Boutourlini's blue monkey (Cercopithecus mitis boutourlinii), a vulnerable subspecies endemic to western 
Ethiopia. 2020; 61:785-796.

7. Grubb P, Butynski TM, Oates JF, Bearder SK, Disotell TR, Groves CP and Struhsaker TT. Assessment of the diversity of African primates. Int J Primatol. 2003; 24, pp.1301-1357.

8. IUCN Red List of Threatened Species. 2008 Website: <http://www.iucnredlist.org/>. (Accessed on August 10, 2018).

9. Mekonnen A, Fashing PJ, Bekele A, Hernandez-Aguilar RA, Rueness EK \& Stenseth NC. Dietary flexibility of Bale monkeys (Chlorocebus djamdjamensis) in southern Ethiopia: Effects of habitat degradation and life in fragments. BMC ecology. 2018; 18, 4.

10. Cords M. Foraging and safety in adult female blue monkeys in the Kakamega Forest. Eat or be eaten: Predator sensitive foraging among primates. 2002; 205pp.

11. Estes RD. The behavior guide to African mammals: including hoofed mammals, carnivores. Primates. $1991 ; 519$ pp.

12. Chapman CA, Gillespie TR \& Goldberg TL. Primates and the ecology of their infectious diseases: how will anthropogenic change affect host-parasite interactions? Issues, News, and Reviews, Evolu Anthrop. 2005; $14,134-144$.

13. Mark M. Manual of Highland Ethiopian Trees and Shrubs. SIM Forestry study project Injibara, Awi zone. Banawee Printing Press, Ethiopia. 2002.

14. Kibebew E \& Abie K. Population status, group size, and threat to Boutourlini's blue monkeys (Cercopithecus mitis boutourlinii) in Jibat Forest, Ethiopia. J Ecosystem Ecography. 2017; 7: 2. doi:10.4172/21577625.1000230

15. Chapman CA \& Chapman LJ. Constraints on group size in red colobus and red-tailed guenons: examining the generality of the ecological constraints model. Int J Primatol. 2000; 21, 565-585.

16. Mekonnen A. Distribution of the Bale Monkey (Chlorocebus djamdjamensis) in the Bale Mountains and its Ecology in the Odobullu Forest, Ethiopia - A Study of Habitat Preference, Population Size, Feeding Behaviour, Activity and Ranging Patterns. Sc. Thesis. Addis Ababa University, Addis Ababa. 2008.

17. Tesfaye D. Ecology, behavior and conservation of Boutourlini's blue monkey (Cercopithecus mitis boutourlinii) in Jibat Forest, Ethiopia. MSc Thesis, Department of Biology, Addis Ababa University. 2010.

18. Kaplin BA, Munyaligoga V \& Moermond TC. The Influence of Temporal Changes in Fruit Availability on Diet Composition and Seed Handling in Blue Monkeys (Cercopithecus mitis doggetti). Biotropica. 1998; 30, 5671.

19. Tesfaye D, Fashing PJ, Bekele A, Mekonnen A \& Atickem A. Ecological flexibility in Boutourlini's blue monkeys (Cercopithecus mitis boutourlinii) in Jibat Forest, Ethiopia: a comparison of habitat use, ranging behavior, and diet in intact and fragmented forest. Int J Primatol. 2013; 34, 615-640.

20. Geleta M \& Bekele A. Population size, habitat association and dietary composition of Boutourlinis blue monkeys (Cercopithecus mitis boutourlinii) in Komto Protected Forest, western Ethiopia. Int J Biodivers Conserv. 2016; 8, 259-268.

21. Vasey N. Activity budgets and activity rhythms in red ruffed lemurs (Varecia rubra) on the Masoala Peninsula, Madagascar: seasonality and reproductive energetics. Am J Primatol. 2005; 66, 23-44.

22. Kaplin BA. Ranging behavior of two species of guenons (Cercopithecus Ihoesti and mitis doggetti) in the Nyungwe Forest Reserve, Rwanda. Int J Primatol. 2001; 22, 521-548. 
23. Fashing PJ. Feeding ecology of guerezas in the Kakamega Forest, Kenya: the importance of Moraceae fruit in their diet. Int J Primatol. 2001b; 22, 579-609.

24. Ibrahim H, Bekele A \& Yazezew D. Population structure and feeding ecology of Guereza (Colobus guereza) in Borena-Sayint National Park, northern Ethiopia. Int J Biodivers Conserv. 2017; 9, 323-333.

25. Nunn CL \& Barton RA. Allometric slopes and independent contrasts: a comparative test of Kleiber's law in primate ranging patterns. Am Natura. 2000; 156, 519-533.

26. Hussen M \& Ejigu D. Diurnal activity patterns, feeding ecology and conservation status of colobus monkeys (Colobus guereza gallarum) in Gidabo forest, Sidama Zone, Ethiopia. Palgo J Agriculture. 2017; $4: 3,238-245$.

27. Sutherland WJ ed. Ecological Census Techniques: A Handbook. Cambridge University Press, New York. 2006.

28. Altman J. Observational study of behavior: sampling methods. Behaviour. 1974; 49, 227-267.

29. Fashing PJ. Activity and ranging patterns of guerezas in the Kakamega Forest: intergroup variation and implications for intragroup feeding competition. Int J Primatol, 2001a; 22, 549-577.

30. Di Fiore A \& Rodman PS. Time allocation patterns of lowland woolly monkeys (Lagothrix lagotricha poeppigii) in a Neotropical Terra Firma Forest. Int J Primatol, 2001; 22, 449-480.

31. Fairgrieve C \& Muhumuza G. Feeding ecology and dietary differences between blue monkey (Cercopithecus mitis stuh/manni Matschie) groups in logged and unlogged forest, Budongo Forest Reserve, Uganda. Afr J Ecol. 2003; 41, 141-149.

32. Di Fiore A. Diet and feeding ecology of woolly monkeys in a western Amazonian rain forest. Int J Primatol. 2004; 25, 767-801.

33. Di Fiore A. Ranging behavior and foraging ecology of lowland woolly monkeys (Lagothrix lagotricha poeppigii) in Yasunı' National Park, Ecuador. Am J Primatol. 2003; 59, 47-66.

34. Grassi C. Variability in habitat, diet, and social structure of Hapalemur griseus in Ranomafana National Park, Madagascar. Am J Physical Anthrop. 2006; 131, 50-63.

35. Xiang ZF, Huo S, Xiao W, Quan RC \& Grueter CC. Diet and feeding behavior of Rhinopithecus bieti at Xiaochangdu, Tibet: adaptations to a marginal environment. Am J Primatol. 2007; 69, 1141-1158.

\section{Tables}

Table 1: Seasonal diurnal activity time budgets for blue monkeys in Apini and Dokuma groups.

Diurnal activities (\%)

\begin{tabular}{llllllllll}
\hline Group & Season & Feeding & Resting & Moving & Grooming & $\begin{array}{l}\text { Sexual } \\
\text { activity }\end{array}$ & Aggression & Playing & Others \\
\hline Apini & Wet & 48.1 & 17.9 & 15.4 & 10.8 & 1.0 & 0.5 & 1.2 & 5.0 \\
& Dry & 46.8 & 9.8 & 25.6 & 8.4 & 0.7 & 0.9 & 0.8 & 7.0 \\
\multirow{2}{*}{ Dokuma } & Wet & 51.5 & 14.5 & 15.6 & 11.5 & 1.3 & 0.2 & 1.1 & 4.3 \\
& Dry & 45.4 & 12.2 & 21.9 & 12.7 & 0.8 & 0.4 & 0.7 & 5.9 \\
\hline
\end{tabular}


Table 2: Percentage of time spent by the two groups of blue monkeys feeding on different food items during the wet and dry seasons

\begin{tabular}{lcclcc}
\hline & Apini group (\%) & \multicolumn{3}{c}{ Dokuma group (\%) } \\
\hline Diet & Wet season & Dry season & Diet & Wet season & Dry season \\
\hline \multirow{2}{*}{ Stems } & 1.3 & 3.1 & Stems & 0.7 & 0.2 \\
Mature leaves & 7.5 & 5.6 & Mature leaves & 9.2 & 7.1 \\
Young leaves & 62.7 & 41.5 & Young leaves & 44.9 & 33.1 \\
Tree buds & 3.6 & 1.3 & Tree buds & 4.9 & 4.1 \\
Flowers & 1.1 & 5.1 & Flowers & 0.3 & 2.4 \\
Fruits & 22.2 & 39.3 & Fruits & 37.1 & 49.1 \\
Seeds & 1.0 & 1.7 & Seeds & 1.9 & 1.8 \\
Animal preys & 0.7 & 1.9 & Animal preys & 1.0 & 2.2 \\
\hline Total & 100 & 100 & Total & 100 & 100 \\
\hline
\end{tabular}

Table 3: List of plant species, parts consumed, and percentage contribution in the Apini forest 


\begin{tabular}{|c|c|c|c|c|c|}
\hline $\begin{array}{l}\text { al } \\
\text { ae }\end{array}$ & Species & Family & $\begin{array}{l}\text { Life } \\
\text { forms }\end{array}$ & $\begin{array}{l}\text { Parts } \\
\text { consumed }\end{array}$ & $\begin{array}{l}\text { Percentage } \\
\text { contribution }\end{array}$ \\
\hline tsini & Albizia gummifera & Fabaceae & Tree & $\begin{array}{l}\text { YL, FR, FL, ST, } \\
\text { SD }\end{array}$ & 33.6 \\
\hline vi & Hypросratea spp. & Urticaceae & Liana & YL, ML, FR & 29.1 \\
\hline issi & $\begin{array}{l}\text { Croton } \\
\text { macrostachyus }\end{array}$ & Euphorbiaceae & Tree & YL, ML, FR & 6.2 \\
\hline ntsi & Prunus Africana & Rosaceae & Tree & YL, SH & 8.3 \\
\hline ahtahi & $\begin{array}{l}\text { Allophylus } \\
\text { abyssinicus }\end{array}$ & Sapindaceae & Tree & YL, ML & 7.8 \\
\hline ayi & Ficus sur & Moraceae & Tree & YL, ML, FR & 3.0 \\
\hline ringi & Celtis Africana & Cannabaceae & Tree & YL, ML & 2.6 \\
\hline kishi & $\begin{array}{l}\text { Urera } \\
\text { hypselodendron }\end{array}$ & Urticiaceae & Liana & YL, ML & 2.9 \\
\hline iri & Olea europea & Oleaceae & Tree & YL, ML & 1.3 \\
\hline di & Apodytes dimidiate & Icacinaceae & Tree & YL, SH & 1.9 \\
\hline biltigni & Maerua tryphylla & Capparidaceae & Tree & YL, ML & 1.6 \\
\hline ri & Dombeya torrida & Sterculiaceae & Tree & YL, ML & 0.6 \\
\hline ginbi & Mimusops kummel & Sapotaceae & Tree & YL & 0.8 \\
\hline bi & Maesa lanceolata & Myrsinaceae & Tree & YL, FR & 0.3 \\
\hline $\mathrm{tal}$ & & & & & 100 \\
\hline
\end{tabular}

YL: Young leaves, FR: Fruits, ML: Mature leaves, ST: Stem, FL: Flowers, SH: Shoots, SD: Seed

Table 4: List of plant species, parts consumed, and percentage contribution in the Dokuma forest 


\begin{tabular}{|c|c|c|c|c|c|}
\hline $\begin{array}{l}\text { cal } \\
\text { me }\end{array}$ & Species & Family & $\begin{array}{l}\text { life } \\
\text { forms }\end{array}$ & $\begin{array}{l}\text { parts } \\
\text { consumed }\end{array}$ & $\begin{array}{l}\text { percentage } \\
\text { contribution }\end{array}$ \\
\hline ivi & Hyрросratea spp. & Urticaceae & Liana & YL, ML, FR & 35.1 \\
\hline ntsini & Albizia gummifera & Fabaceae & Tree & $\begin{array}{l}\text { YL, FR, FL, ST, } \\
\text { SD }\end{array}$ & 24.7 \\
\hline sissi & $\begin{array}{l}\text { Croton } \\
\text { macrostachyus }\end{array}$ & Euphorbiaceae & Tree & YL, ML, FR & 7.6 \\
\hline mtsi & Prunus Africana & Rosaceae & Tree & YL, SH & 8.9 \\
\hline tahtahi & $\begin{array}{l}\text { Allophylus } \\
\text { abyssinicus }\end{array}$ & Sapindaceae & Tree & YL, ML & 6.4 \\
\hline ıdi & Apodytes dimidiate & Icacinaceae & Tree & YL, SH & 3.5 \\
\hline aringi & Celtis Africana & Cannabaceae & Tree & YL, ML & 2.2 \\
\hline nkishi & $\begin{array}{l}\text { Urera } \\
\text { hypselodendron }\end{array}$ & Urticiaceae & Liana & YL, ML & 3.4 \\
\hline ali & Combretum molle & Combretaceae & Tree & YL, FR & 2.1 \\
\hline uiri & Ekebergia capensis & Meliaceae & Tree & YL & 1.5 \\
\hline ari & Dombeya torrida & Sterculiaceae & Tree & YL, ML, FL & 1.9 \\
\hline ıuyi & Ficus sur & Moraceae & Tree & YL, ML, FR & 1.1 \\
\hline lbiltigni & Maerua tryphylla & Capparidaceae & Tree & YL, ML & 1.3 \\
\hline kitsi & $\begin{array}{l}\text { Vernonia } \\
\text { amygdalina }\end{array}$ & Asteraceae & Tree & YL & 0.3 \\
\hline tal & & & & & 100 \\
\hline
\end{tabular}

YL: Young leaves, FR: Fruits, ML: Mature leaves, ST: Stem, FL: Flowers, SH: Shoots, SD: Seed

Table 5: Activity time budgets devoted to different activities by members of the genus Cercopithecus from studies in different parts of Africa

\begin{tabular}{|c|c|c|c|c|c|c|c|c|}
\hline \multirow[b]{2}{*}{$\overline{\text { ecies }}$} & \multicolumn{6}{|c|}{$\%$ of time contribution } & \multirow[t]{2}{*}{ country and site } & \multirow[t]{2}{*}{ Reference } \\
\hline & $\mathrm{F}$ & FR & $\overline{\mathrm{M}}$ & $\overline{\mathrm{R}}$ & S & Os & & \\
\hline $\begin{array}{l}\text { orcopethicus mitis } \\
\text { outourlini }\end{array}$ & 48.1 & - & 19.4 & 13.8 & 13.3 & 5.5 & $\begin{array}{l}\text { Apini and Dokuma } \\
\text { forest, Ethiopia }\end{array}$ & This study \\
\hline mitis boutourlini & 48.4 & - & 17.9 & 21.7 & 12.0 & 0.0 & Jibat forest, Ethiopia & $\begin{array}{l}\text { Tesfaye et al. } \\
2013\end{array}$ \\
\hline lhoesti & 45.1 & 2.5 & 23.0 & 14.0 & 10.0 & 5.0 & $\begin{array}{l}\text { Nyungwe forest } \\
\text { reserve, Rwanda }\end{array}$ & Kaplin, 2001 \\
\hline mitis doggetti & 44.6 & 2.4 & 20.0 & 16.0 & 11.0 & 0.0 & $\begin{array}{l}\text { Nyungwe forest } \\
\text { reserve, Rwanda }\end{array}$ & Kaplin, 2001 \\
\hline mitis stuhlmanni & 60.3 & - & 19.7 & 9.9 & 8.3 & 1.8 & $\begin{array}{l}\text { Kibale } \\
\text { Uganda }\end{array}$ & $\begin{array}{l}\text { Butynski, } \\
1990\end{array}$ \\
\hline campbeelli & 48.5 & - & 28.0 & 18.0 & 5.2 & 0.3 & Tai, Ivory Coast & $\begin{array}{l}\text { Buzzard,2004; } \\
2006\end{array}$ \\
\hline Diana & 40.6 & - & 27.7 & 24.4 & 7.3 & 0.0 & Tai, Ivory Coast & $\begin{array}{l}\text { Buzzard, } \\
\text { 2004; } 2006\end{array}$ \\
\hline
\end{tabular}


Table 6: Comparison of percentage of feeding records on different food items by members of the genus Cercopithecus in Africa

\begin{tabular}{|c|c|c|c|c|c|c|c|c|c|c|c|c|c|}
\hline cies & YL & ML & TL & $\mathbf{R}$ & FL & FR & SH & ST & AP & SD & $\mathrm{BA}$ & country & reference \\
\hline $\begin{array}{l}\text { opethicus } \\
\text { is } \\
\text { tourlinii }\end{array}$ & 46.3 & 7.5 & 53.8 & - & 2.3 & 36.3 & 3.6 & 1.4 & 1.4 & 1.6 & & $\begin{array}{l}\text { Apini and } \\
\text { Dokuma } \\
\text { Forest, } \\
\text { Ethiopia }\end{array}$ & $\begin{array}{l}\text { This } \\
\text { study }\end{array}$ \\
\hline $\begin{array}{l}\text { nitis } \\
\text { tourlinii }\end{array}$ & 27.4 & 20.3 & 47.7 & - & 11.2 & 15.4 & 8.99 & - & 3.4 & 4.9 & 6.9 & $\begin{array}{l}\text { Komto } \\
\text { Forest, } \\
\text { Ethiopia }\end{array}$ & $\begin{array}{l}\text { Geleta } \\
\text { and } \\
\text { Bekele, } \\
2016\end{array}$ \\
\hline $\begin{array}{l}\text { nitis } \\
\text { tourlini }\end{array}$ & 14.4 & 3.9 & 18.3 & - & 7.0 & 32.4 & 20.6 & - & 13.8 & 5.7 & 1.6 & $\begin{array}{l}\text { Jibat } \\
\text { Forest, } \\
\text { Ethiopia }\end{array}$ & $\begin{array}{l}\text { Tesfaye } \\
\text { et al. } \\
2013\end{array}$ \\
\hline $\begin{array}{l}\text { nitis } \\
\text { getti }\end{array}$ & - & - & 6.4 & - & 6.2 & 47.4 & - & - & 24.9 & 9.3 & - & Rwanda & $\begin{array}{l}\text { Kaplin, } \\
2001\end{array}$ \\
\hline scanius & - & - & 34.7 & - & 2.7 & 44.6 & - & - & 17.6 & - & - & $\begin{array}{l}\text { Kibale at } \\
\text { Sebatoli, }\end{array}$ & $\begin{array}{l}\text { Chapman } \\
\text { et al. } \\
2004\end{array}$ \\
\hline scanius & - & - & 28.8 & - & 3.7 & 35.7 & - & - & 31.2 & - & - & $\begin{array}{l}\text { Kibale at } \\
\text { Kanyawara, } \\
\text { Uganda }\end{array}$ & $\begin{array}{l}\text { Chapman } \\
\text { et al. } \\
2004\end{array}$ \\
\hline iictitans & 10.0 & 0.1 & 10.1 & - & 4.1 & 35.5 & - & - & - & 50.2 & - & Makand'e & $\begin{array}{l}\text { Brugiere, } \\
2002\end{array}$ \\
\hline ogonias & 13 & 0.1 & 13.1 & - & 4.7 & 26.9 & - & - & - & 49.8 & - & $\begin{array}{l}\text { Makand'e } \\
\text { Forest, } \\
\text { Gabon }\end{array}$ & $\begin{array}{l}\text { Brugiere, } \\
2002\end{array}$ \\
\hline
\end{tabular}

YL: Young leaves; ML: Mature leaves; TL: Total leaves; R: Root; S: Stem; FL: Flower; FR: Fruit; SH: Shoot; AP: Animal preys; SD: Seeds; BA: Bark

\section{Figures}




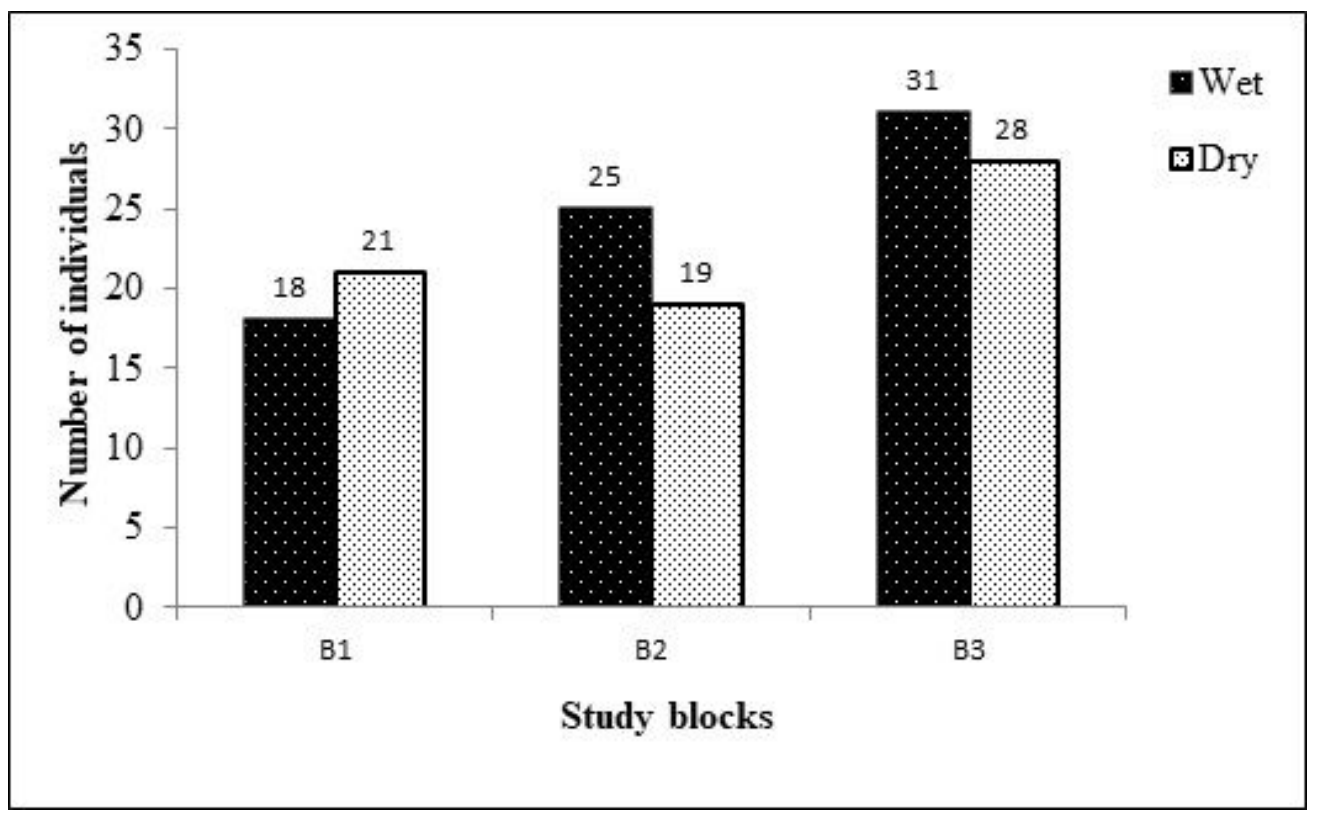

Figure 1

The individual numbers of blue monkeys counted in different blocks during the wet and dry season in Apini forest

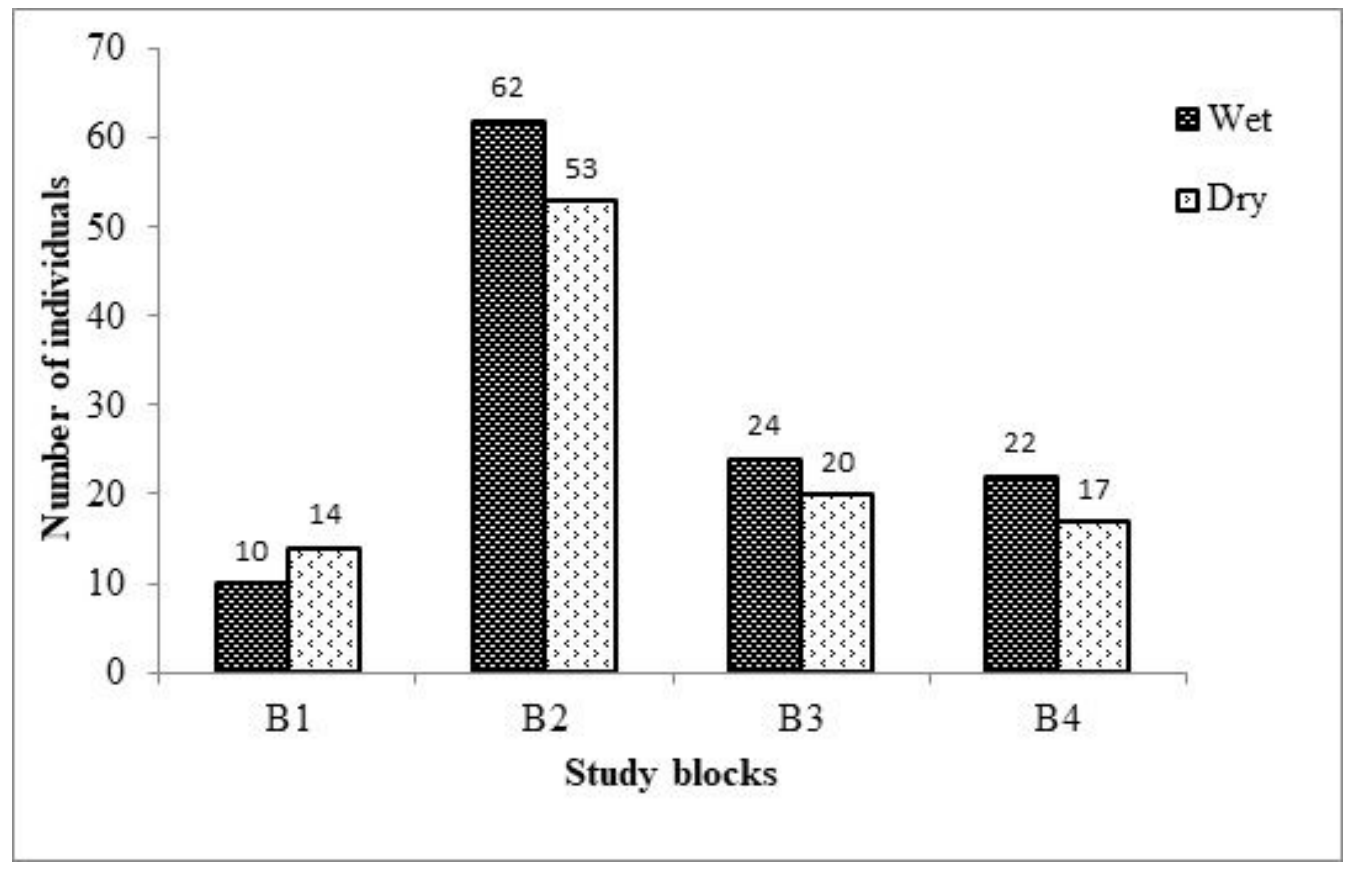

Figure 2

Individual numbers of blue monkeys counted in different blocks during the wet and dry season in Dokuma forest 


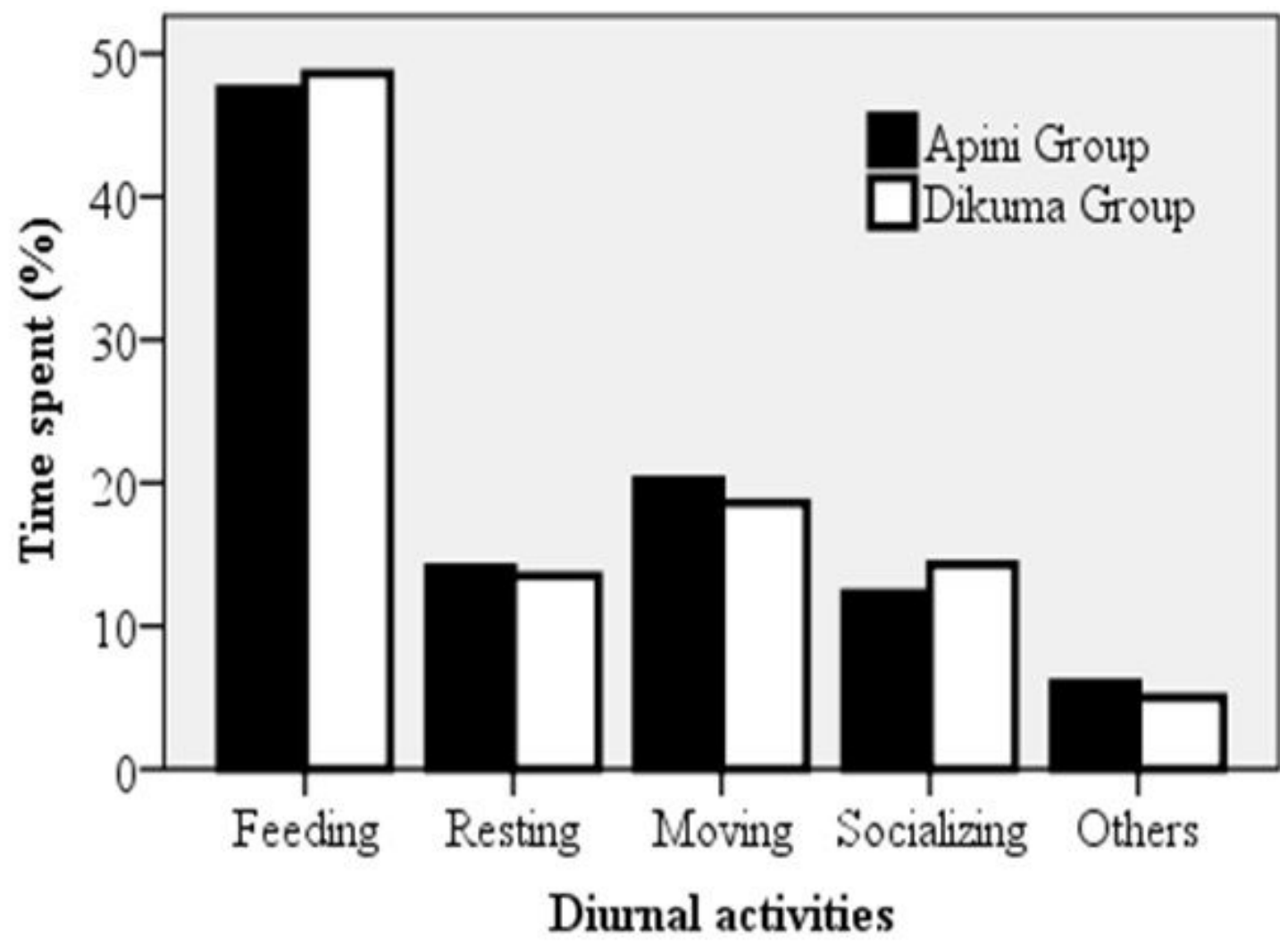

Figure 3

Overall activity patterns of Apini and Dokuma groups of blue monkeys

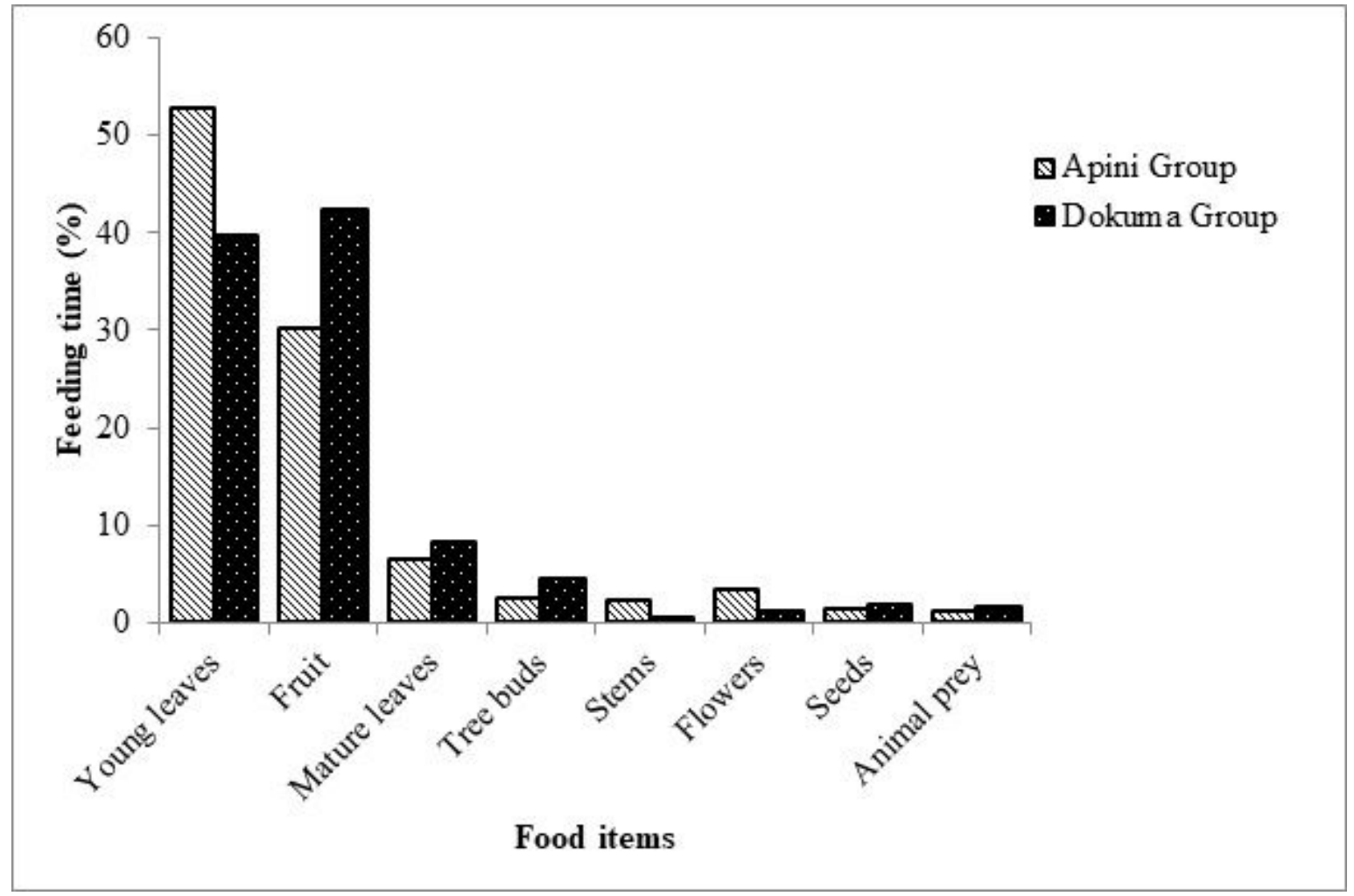

Figure 4 
Percentage contribution of food items consumed by blue monkeys in Apini and Dokuma groups

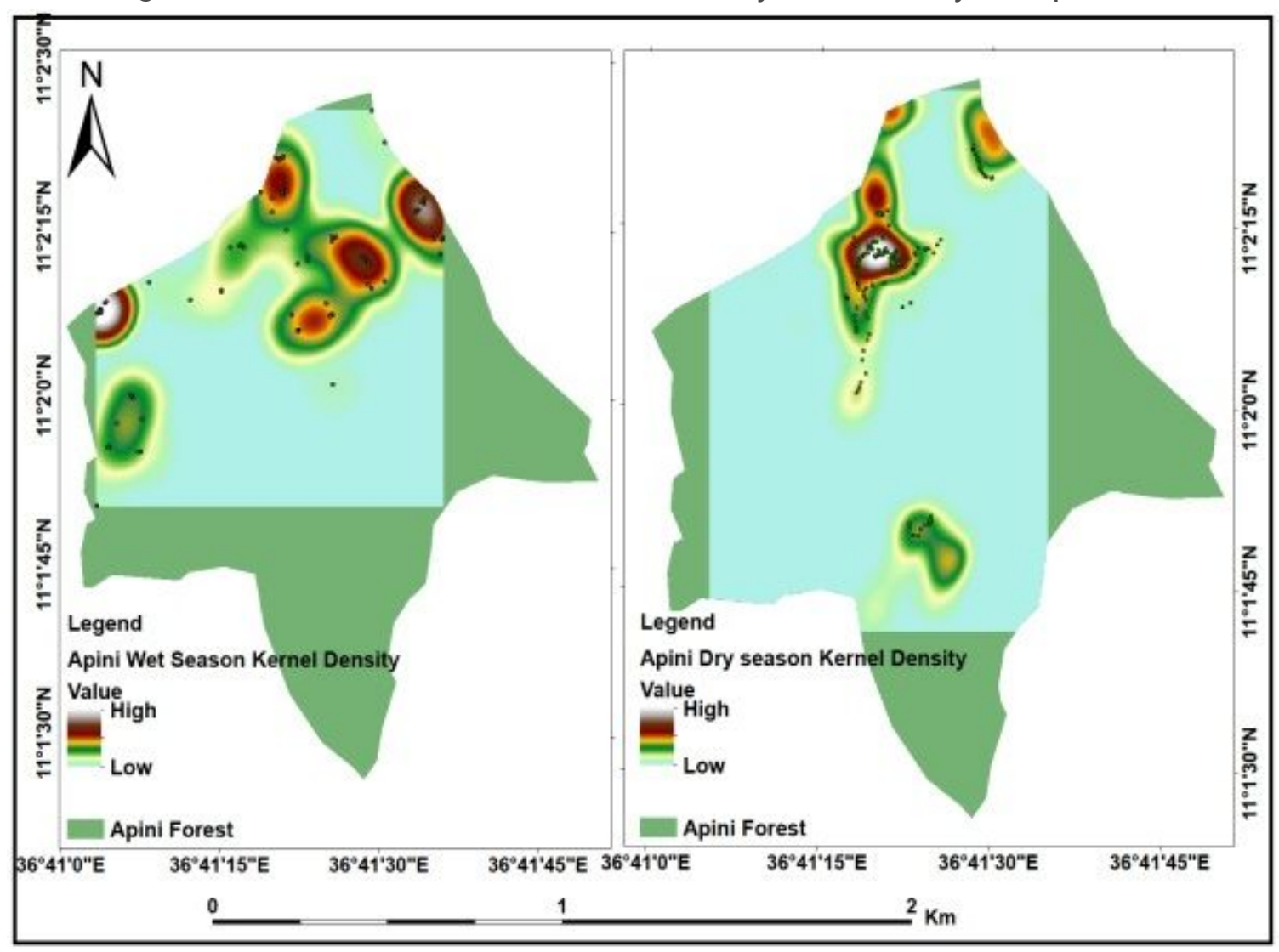

\section{Figure 5}

Home range size of blue monkeys in the Apini forest between the wet and dry seasons 


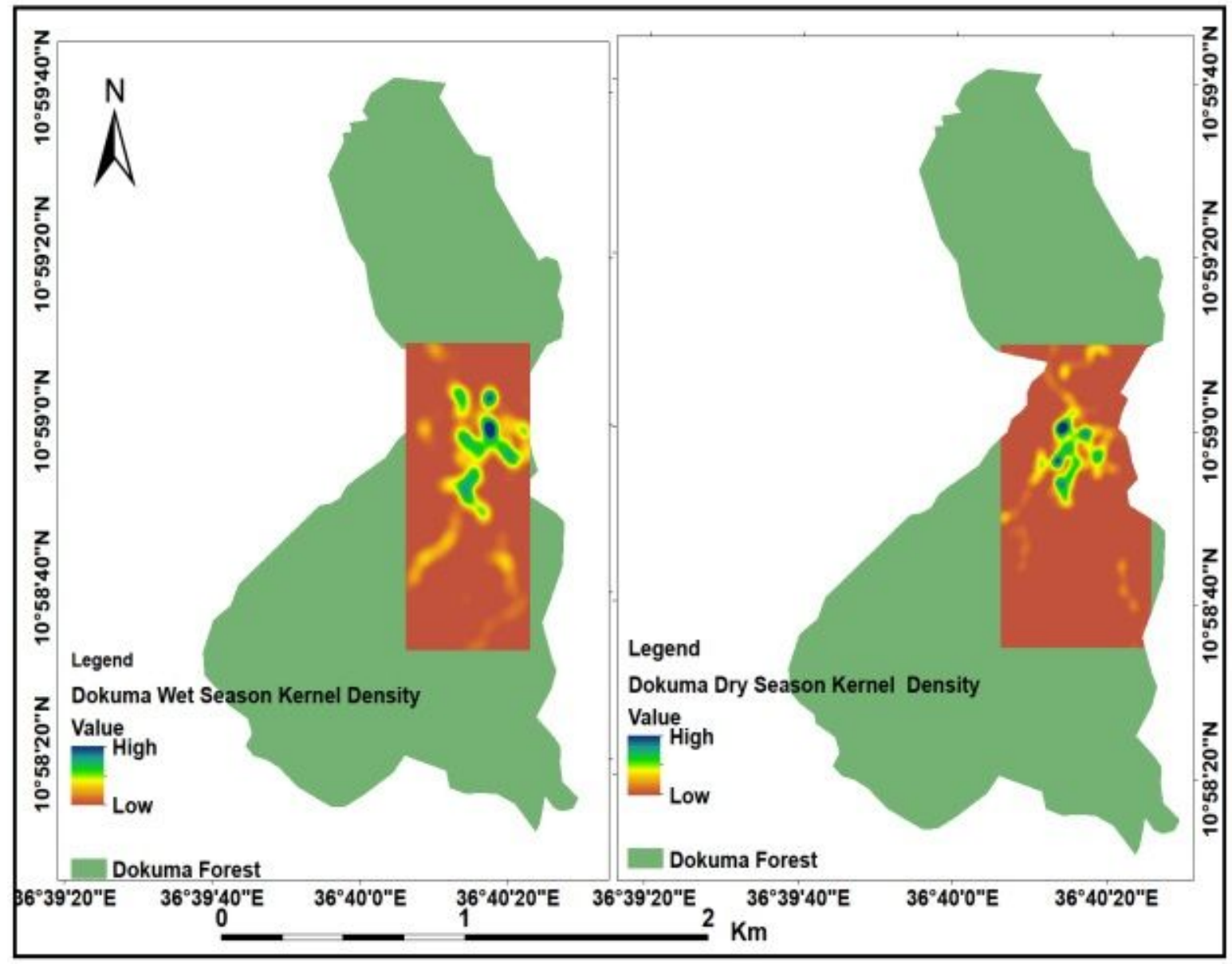

Figure 6

Home range size of blue monkeys in the Dokuma forest between the wet and dry seasons

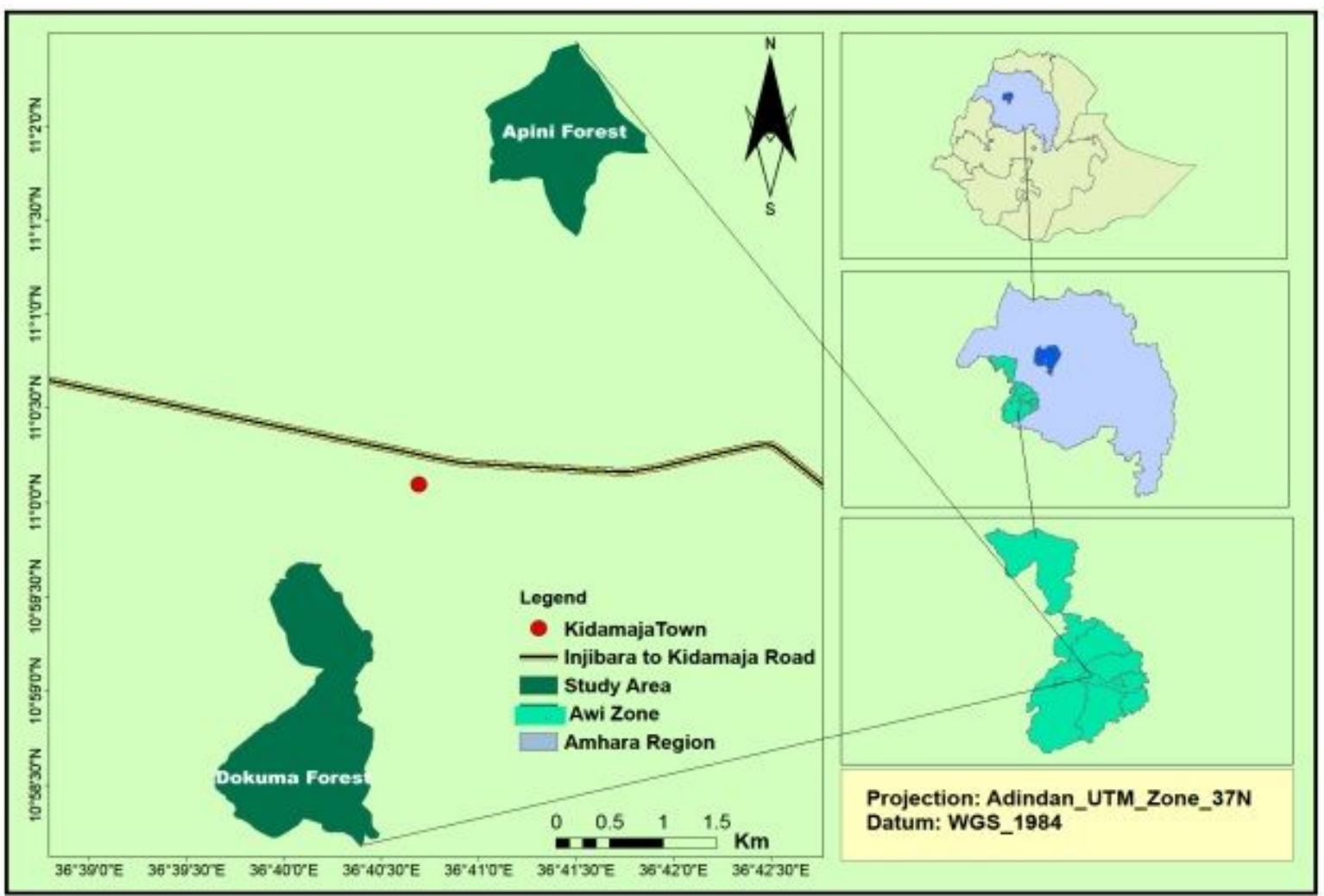


Figure 7

Location map of the study areas

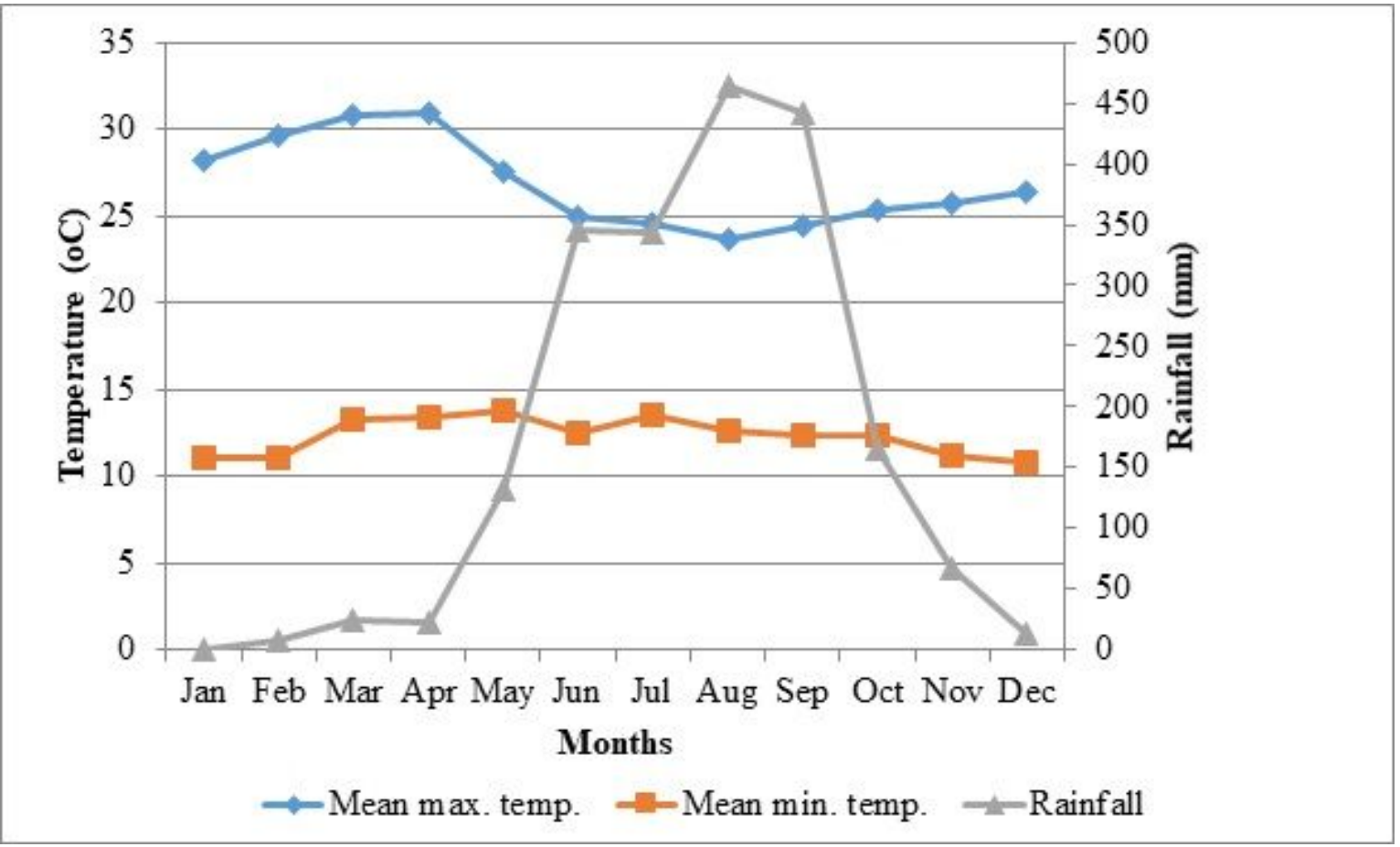

Figure 8

The mean monthly minimum and maximum temperature and rainfall of the study area in the years from 20092018. (Source: West Amhara Meteorology Agency).

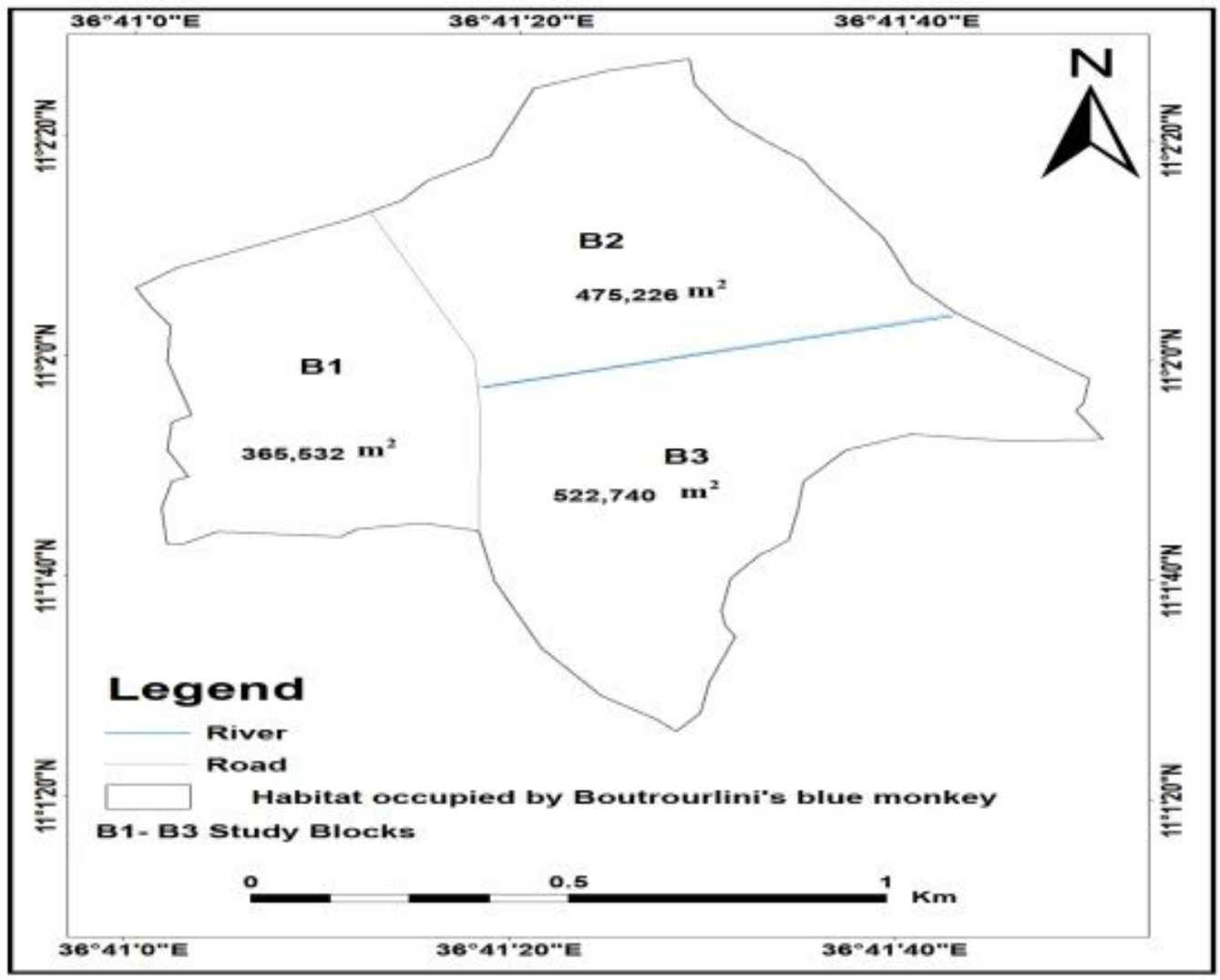


Figure 9

Population counting blocks in the Apini forest

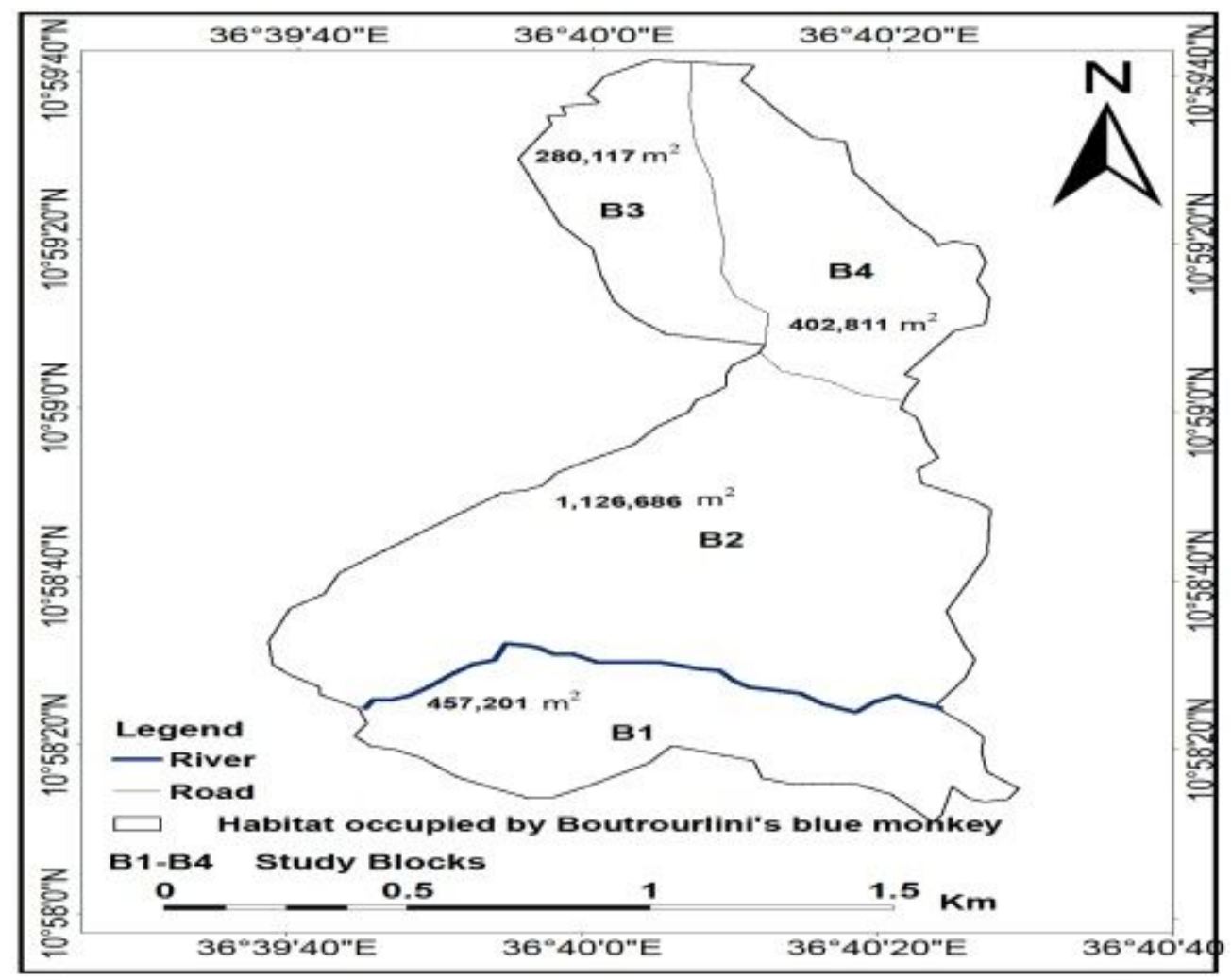

Figure 10

Population counting blocks in the Dokuma forest 